\title{
The Partition of Indian Sub-continent: Problems and Literary Prospects
}

\section{Dr. Roopesh Chaturvedi}

Even before 1947, the concept of dividing a country into two was not new to India. India had known it earlier in 1905 with the bifurcation of Bengal. But the partition of India in 1947, into India and Pakistan, was unique in multitudinous ways: No other country in the world was ever before divided on the basis of religion. Besides, mass migration of the kind, before the partition of India, was unknown to the world. Germany and Korea had been through the process of division, but they did not experience the kind of calamity.

'Partitioning two lives is difficult enough. Partitioning millions is madness'.

The partition of India was not merely a historical fact but it was an example of Indian tendency to forget everything that brings with it some kind of agony. India seems to be scared recalling the memory of the unpleasant past, unlike the other countries of the world. Japan commemorates every year the atomic attack that has destroyed it. India rarely remembers that China has defeated her in the recent past.

The political history of the event describes hundreds of problems as the instant by-products of the partition; each of them is deeply rooted in the helplessness of the humanity.

The time from June 3,1947 - when the partition was announced - to August 15, 1947, the date of the transfer of power to the two new dominions was seventy- three days in all. 'There were exactly 73 days before 15 August in which to draw up the divorce paper.' ${ }^{3}$ It took only a few days to locate the problems and set up the machinery of division of India. Within this period a host of problems had to be solved and innumerable administrative tasks had to be undertaken and to be concluded. With a bare five weeks in which to decide (Radcliffe arrived in India on July 8, 1947, and the awards was announced on August 16, 1947) and geographically fix the limits of India and Pakistan. 'Radcliffe knew virtually nothing about India'. ${ }^{4}$ He got down to the momentous task of deciding a boundary that would divide a dominion of more than 35 million people, thousands of villages, towns and cities, a unified and integrated system of canals and communications, and 16 million Muslims, 15Million Hindus and 5 million Sikhs, who despite their religious contrariety shared a common culture, language and history. 'Cyril Radcliffe's scalpel had severed the tumour, but it had not been able to carve out the cancerous cells infecting each half', 5

One of the most tragic and serious problems that emerged as the instant by-product of the partition was the transfer of population. Beginning with months before 15 august 1947, the migration was largest in human history. The migration was not at all very safe:

The forty-five miles of roadside from Lahore to Amritsar along which so many passed became a long, open grave yard... and every yard of the way... there was a body, some butchered some dead of cholera. The vultures had become so bloated by their feasts they could no longer fly and the wild dogs so demanding in their taste they ate only the liver of the corpses littering the road. ${ }^{6}$

The problem of division of assets of India between India and Pakistan was not an easy one to solve. It kept the Indo-Pak relations tense and strained during the initial years of their freedom. 'Different categories of assets had to be examined separately and divided on an equitable basis.' 7 On August 14, 1947, the cash balance of India was about Rs 4000 million, out of which Pakistan wanted Rs 1000 million. India was not in favour of paying such a big amount to the neighbour. The arbitrary tribunal decided the case and ordered that Rs 750 million should be paid to Pakistan. After initial hesitation, India decided to implement the agreement. However, Pakistan in his turn, refused to pay India Rs 55 crores, which Pakistan had to pay as the share of pre-partition debt.

It was not only the banknote and book and furniture that had to be sorted out and went through the process of division, so too, did hundreds of thousands of human being were given choice of serving India or Pakistan. Then, separated into human columns public employees from railroad president and junior ministers to sweepers, errand boys, bearers and clerks, transported off to one dominion or the other. The communal riots had even compelled them to abandon their immobile properties in their parents' countries.

The division of Punjab into west Punjab, which came to be as a part of Pakistan and east Punjab, which remained with India brought with it the problem of distribution of canal waters. The problem arose out of the 
unnatural partition of Punjab. 'The dispute broke into the open on April 1,1948, when east Punjab in India cut off the flow of canal waters to west Punjab in Pakistan. ${ }^{8}$

The problems on physical level where far more numerous and onerous for Pakistan than for India. The government of India in Delhi was a going concern, which would continue to function much the same as before, except that it would cease to exercise jurisdiction over the areas of Pakistan. The system of currency and banking together with other economic and financial institution was operating on an all India basic and its regulation remained in the hands of government of India. The India railways, posts and telegraph linked the various parts of the subcontinent in a unified system of communications controlled from Delhi. Almost all the prominent industrial installations and research institutions of the Government of India were situated in the territories of Indian union. Central Government archives and records were in Delhi and the imperial library was in Calcutta. Army, air force and major head quarters were located in the Indian dominion. The recognition and division of the armed forces presented India with far fewer problems than Pakistan.

As part of the partition settlement, it was agreed that after 15August, 1947, the British paramountancy over the princely states would lapse and these states would be free to accede either to India or to remain independent. Gradually all the princely states decided their future except the rulers of 'Junagadh', 'Hyderabad' and 'Kashmir'. They decided to avoid the decision. The issue of accession of these three states led to the development of tensions between India and Pakistan. Somehow, the controversy over Junagadh and Hyderabad was settled but Kashmir became the apple of discard between the two countries. The problem over Kashmir still remained unresolved threatening the peace of the subcontinent.

Political history presents a series of events preceded the partition of India. It includes the growing tension between both the prominent political parties, before the partition of India: the Congress and Muslim League, the debate between Nehru and Jinnah, Nehru and Patel, helplessness of Gandhi and host of other developments were merely on the political grounds. The political history of the partition recklessly concentrates upon the series of incidents accompanied and followed the partition of India in 1947: Violence, mass migration, refugeeism, and rehabilitation - all on the surfacial level. According to the history, the partition seems to lie only in political developments and the geographic bifurcation of the land. The other aspect - what had happened to the millions of people who had to live through this time that can be called the human dimensions of history of the partition - somehow seemed to have less prominent status in it. Perhaps this was so, because the governments had to deal with the more difficult things on political level: loss and sharing, friendship and enmity, grief and joy, with a painful regret and nostalgia for loss of home, country and friends and with an equally strong determination to create them afresh. On the ground of reality, these were difficult things to capture, but their place in history of the partition could not be denied.

The human dimension of the partition is the most decisive element shaping the political relationship between India and Pakistan. For every unhealthy development, if it is at all possible, India blames Pakistan for it. And why does Pakistan involve itself in matters of India has its roots in selfdom crisis. The problem of individual crisis of identity in Pakistan is collectively responsible for unhealthy relationship of India with Pakistan.

A geographical and political division, in no way, has weakened the emotional bond between the people living across the border and those who crossed over to this side following the separation of India. People speak fondly of their past, though the horrifying memories of the partition still haunt them. They live in the past and wish if they could live as they used to before 1947, with no foreign rule.

On individual level Urvashi Butaliya, penetratingly recapitulates the feeling of uprootedness, a typical example of crisis of identity. Her uncle, however a Hindu, decided to live in Pakistan with his mother. He embraced Islam to live happily in Pakistan. But when he saw his dear departed ones, he could not help disclosing his inner state of mind. His niece reveals:

Home for him was defined in many different ways. Ever since television made its appearance, Ranamama, made sure he listened to the Indian news every day. When cricket was played between the two countries, he watched and secretly rooted for India. Often, when it was India playing another country, he sided with India. More recently, he sometimes watched Indian soaps on the small screen. Although he had told me that his home in Lahore was the only home he had ever known, it was to India that he turned for a sense of home. ${ }^{9}$

One is always nostalgic about the soil he is born, 'In 1947, there was no doubt in my mind I would opt for Pakistan', ${ }^{10}$ says writer Khushwant Singh. But leaving the birthplace was better, though not easy, than living under the dagger.

The sense of belonging of Pakistan for India and the crisis of identity of Pakistan, have its roots in the human aspects of the history of the partition that play its role in determining the fate of both the nations. The human dimension and the theme of displaced sensibility, the byproducts of the partition, provide ample scope for the literary reproduction of the event. 


\section{References}

[1]. Butaliya, Urvashi, The Other Side of Silence, Penguin India, 1998, 80

[2]. Ibid., p. 7.

[3]. Collins, Larry and Dominique Lapierre, Freedom at Midnight, New Delhi, Vikas Publishing House, $1999,212$.

[4]. Ibid., p. 226.

[5]. Ibid., p. 368 .

[6]. Ibid., p. 406.

[7]. Ali, Chaudhari Muhammad, The Emergence of Pakistan, New York \& London, Columbia University Press, $1967,161$.

[8]. Ibid., p. 316.

[9]. Butaliya, Urvashi, The Other Side of Silence, Penguin India, 1998, 38-39.

[10]. The Hindu Folio, August 1997, 15. 